\title{
INSTITUTIONAL AND SOCIO-CULTURAL DIMENTIONS OF POST-COMMUNIST TRANSFORMATIONS
}

\section{Sviderska O. I., Uhryn L. Ya.}

\section{INTRODUCTION}

The development of modern societies, marked by the processes of fragmentation, atomization, and individualization, neutralizes the hierarchical model of the institutional order, dominant over the previous centuries, that necessarily has to take into account the influence of network and transnational structures. These shifts of a global nature have brought into question the effectiveness of democratic institutions, above all the nationstate, their ability to ensure the consolidation and integration of societies diverse in social, regional, cultural and value characteristics and to respond to new civilizational challenges. If institutions are unable to adapt to change, then the society faces crisis and becomes vulnerable to external influences. "Adaptive institutions, as F. Fukuyama claims, are survivors, because environments are ever-changing" . Consequently, adapting institutions to change and transforming the institutional order are significant factors in the development and survival of modern societies and states - both democratic and authoritarian. But it is essentially important for transitional or transit societies to establish the institutional order that can fundamentally change them. A stable institutional order is an indicator of the effective completion of the democratic transit, that is, of the consolidation of democracy and its absence is not only a threat to the return to authoritarianism, but also a decline to the rank of "weak" or "failed" states that lost their subjectivity under the conditions of today's global order. Most researchers who use these concepts (M. Beissinger, B. Buzan, G. Sorensen, etc.) consider the institutional weakness, inability of institutions to meet the needs of citizens their main indicators.

The problems of institutional aspects of post-authoritarian transitions are most completely reflected in the transitological paradigm. Its leading representatives interpret democratic transits as a stage of political development within which qualitative changes and fundamental

1 Фукуяма Ф. Політичний порядок і політичний занепад. Від прадавніх часів до Французької революції. Київ, 2019. С. 472. 
transformations of the political regime take place. Their purpose is usually declared to be a consolidation of democracy, but the path to it is characterized by considerable unpredictability and overall uncertainty about the results. V. Bunce points to the "double uncertainty" of transition societies - a combination of uncertainty of results and uncertainty of procedures $^{2}$. They form the environment of transformation in which "events are sudden, actors are atypical, identities are unstable, institutions are not functioning, support is impossible to anticipate, choice is hurried and risks are inevitable, and they cannot be insured against" "3. As a result, societies in the process of transitioning from one type of political regime to another face the problem of overcoming the uncertainty of social development and the conscious choice of trajectory. They can achieve the desired democracy through the institutionalization of insecurity or they may end up in a long transition and regime hybridization, which is characterized by cyclical "rollback" from democracy because of economic inefficiency, spread of populist ideologies and escalation of security concerns. Socio-political processes in Ukraine are also embedded in the latest cycle of "rollback", which is gradually gaining a global dimension, extending not only to traditional Latin American regions and post-Soviet space, but also to the consolidated young democracies of Central and Eastern Europe and even the "old" democracies of the West. One of the causes of the crisis of democratic institutions, the strengthening of authoritarian tendencies is the influence of information and manipulation technologies. R. Wodak explains these processes by "blurring the boundaries in politics between the real and the fictional, the informative and the entertaining. This creates for the viewer a reality that seems orderly and manageable - and, accordingly, represents a deceptively simple illusion contrary to the very real complexity and pluralism of modern societies"4. These tendencies, which often destabilize public processes in "new" democracies, draw attention to rethinking the problems of formation or transformation of the institutional order in the changing world within transit processes, to elucidate the reasons for the inefficiency of democratic institutions, their failure to maintain consensus and dialogue in the information society and to enable the functioning of the social system as a whole. It should be pointed out that these issues are C. 47 .

2 Банс В. Элементы неопределенности в переходный период. М., 1993.

3 Карл Т. Л. Демократизация: концепты, постулаты, гипотезы. Размышления по поводу применимости транзитологической парадигмы при изучении посткоммунистических трансформаций. Москва, 2004. С. 10-11.

4 Водак Рут (Ruth Wodak). Политика страха. Что значит дискурс правых популистов? Харьков, 2018. C. 46. 
conceptualized in the studies of both Western (e.g., B. Geddes, L. Diamond, G. O'Donnell, F. Zakaria, T. L. Karl, Th. Carothers, T. Kuzio, J. Linz, M. McFaul, A. Przeworski, A. Stepan, Ph. Schmitter, A. Schedler) and Ukrainian researchers (O. Bezruk, R. Karahioz, A. Kolodii, Yu. Matsiyevsky, L. Nahorna, N. Pashyna, N. Pelahesha, L. Pryimak, O. Romaniuk, I. Titar, S. Feduniak, H. Shypunov). Due to the dynamic and "zigzag" (Yu. Matsiyevsky) changes that are taking place in Ukraine, this issue does not lose interest as a subject of research. Since the countries in transit, including Ukraine, give the state significant levers of influence on the formation of social order, transformation of socio-political mechanisms of the democratic system operation - the need for a thorough study of the specific character, functioning, complications and distortions of political institutions under the conditions of democratic transit, development of institutional structure as a whole has taken on new relevant significance.

\section{Institutional aspects of democratic transits. Formal and informal institutions}

Post-authoritarian and post-communist transits and transformations are most conceptualized within the framework of the transitological and neoinstitutional paradigms, which, in our view, are methodologically complementary. Despite certain differences in the interpretations of transition processes within these paradigms, their generalization makes it possible to distinguish the following common features of transits and postauthoritarian transformations. Firstly, it is the diversity of transition models, their consequences, caused by differences in structural conditions, above all by previous development, initial economic conditions, and therefore available resources for reform; secondly, as we have already noted, uncertainty about the development and unpredictability of the consequences; thirdly, the dominant role of political elites in the political process and their competition for power and public resources; fourthly, the activity of society (its civic institutions) the support of which the rival groups of elites appeal for, which generally creates conditions for democratization of the power and society; and, in the fifth place, the absence in most cases of a clear image of the new society and the direction of its transformation that was usually formulated through abstract for the masses concepts - democracy, justice, liberation, and the impact of which was later offset by socio-economic difficulties.

Prerequisites for "launching" transit processes are also diverse: crises of legitimacy due to economic inefficiency; crises of integration through ethnic or regional conflicts, political changes in leadership, defeat in war; disappearance of external support from other states, etc. According to 
A. Melville, real transitions from democratic regimes are so diverse that they are simply unrealistic to bring down to a common denominator, although in case of successful democratization the events develop according to a certain logical system ${ }^{5}$, unfolding from the stage of liberalization of authoritarian regime, democratization and resulting in the consolidation of a new regime either democratic or new authoritarian, or hybrid, which, however, indicates the incompleteness of the transit itself.

Thus, within the framework of classical transitology, the consolidation of democracy (or the new regime) was viewed as the result of intra-elite and social interactions, the process of "the transformation of accidental arrangements, norms of moderation and conditional decisions that emerge in a transitional period into the relations of co-operation and rivalry that occur openly, on a regular basis and are voluntarily accepted by the people and groups participating in the democratic rule. Under consolidation, the democratic regime guarantees its citizens that the competition for power or

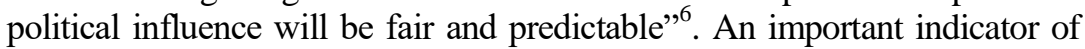
consolidation processes, therefore, is the institutionalization of new rules (institutions), first of all, of the competition for power and resources, conflict resolution and their recognition by all the participants in the political process. A. Przeworski also stresses that consolidation comes when no one thinks about acting outside democratic institutions, when all that the losers want is to try to play again within the same institutions in which they have just lost"'. In other words, consolidation of democracy involves the formation and adoption of democratic institutions, norms, rules and procedures that must ensure the implementation of democratic values, their effectiveness and overcoming of insecurity. Intra-elite and broader - political compromises between actors, which are reflected in the metaphorical definitions of reformist models of transit such as a "pact", "bargaining", "round table", etc., are becoming strategies and mechanisms for the formation of such rules (institutions) and, as a result, for the consolidation of democracy. When it comes to the consolidation of a new authoritarian regime, it relies on forceful strategies that ensure the dominance of one group within the political elite and shape the model of "constrained transformations" with a minimal civil

${ }^{5}$ Мельвиль А. Ю. Демократические транзиты, транзитологические теории и посткоммунистическая Россия. Москва, 2000. С. 337-368.

6 Карл Т. Л. Демократизация: концепты, постулаты, гипотезы. Размышления по поводу применимости транзитологической парадигмы при изучении посткоммунистических трансформаций. Москва, 2004. С. 10.

${ }^{7}$ Пшеворский А. (Adam Przeworski) Демократия и рынок. Политические и экономические реформы в Восточной Европе и Латинской Америке. Москва, 1999. C. 47. 
society's role. At the present stage, authoritarian regimes can use predominantly manipulative techniques for influencing public opinion and use democratic procedures - elections, referendums - for preserving their power.

Systemic transformations of the democratic transition occur when previous political and economic institutions, and rules are destroyed or decayed, but a new democratic system of institutions, whose main function is to restore social equilibrium, is not created. In this context, it is possible to distinguish exogenous and endogenous factors of the democratic transit. The former include the presence and nature of "pre-authoritarian" political experience, a type of undemocratic collapsing regime, the conditions and circumstances of the authoritarian breakup process, the strategies for behaviour during the democratic transit that are formed and consciously chosen by political actors and others. The latter factors include the external environment, the level of involvement in international structures and institutions, the extent of international political, economic and other support, etc.

The certainty of institutional transformations within the transition and the construction of a new institutional design determine the relevance of use of neo-institutional methodology in the studies of post-authoritarian transits. Within this framework, institutions are broadly defined as rules of game, models of interaction that guide relationships between individuals. They can be formal rules, written laws, formal social customs and informal rules of conduct $^{8}$. J. March and J. Olsen accentuate the adaptive and stabilizing functions of institutions, defining them as "a relatively enduring collection of rules and organized practices, embedded in structures of meaning and resources that are relatively invariant in the face of turnover of individuals and relatively resilient to the idiosyncratic preferences and expectations of

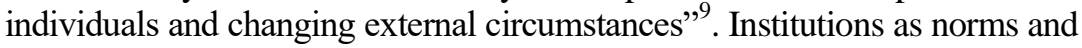
rules, by F. Fukuyama's definition, formulate "stable, important, repetitive patterns of behaviour", which persist even after the change of persons occupying the key positions" ${ }^{\prime 10}$. In fact, the scientist considers institutions to be stable rules, according to which the human behaviour is set, limited and directed. D. North also emphasizes "that institutions should be obliged to

${ }^{8}$ Норт Д. Насильство та суспільні порядки. К., 2017. 352 с.

9 The New Institutionalism: Organizational Factors in Political Life Author(s): James G. March and Johan P. Olsen Source. The American Political Science Review, 1984, pp. 734-749

10 Фукуяма Ф. Політичний порядок і політичний занепад. Від промислової революції до глобалізації демократії. Київ, 2019. С. 15. 
warn about the means of complying with rules and regulations" ${ }^{\prime 1}$. The scientist claims that the same institute can function differently in different social environments. Therefore, in the process of analysing the functioning of institutions, it is important to determine the role of organizations and perceptions, depending on the social order and historical periods of the time when institutions regulated the organizations' formation ${ }^{12}$. In this context, the state is a whole of organizations and institutions that have their own interests, and political decisions are conditioned by the interests of institutional actors rather than by the response to the surrounding pressure ${ }^{13}$. Yet, "the state, according to F. Fukuyama, is also determined by electoral institutions designed to ensure its movement in the line of popular will, rather than simply serving the selfish interests of the ruling elite" 14 .

The analysis of institutional aspects of democratic transit, based on the principles of neo-institutionalism, allows us to consider the actions of political actors also within formal and informal institutions, whose models of interaction determine the institutional design of transitional regimes. Informal institutions are created evolutionarily, "from the grassroots", without conscious intention, as a by-product of the interaction of many people intending to satisfy their own interests. Formal institutions and mechanisms for their protection are established and maintained from above, deliberately, most often by the power of the state. Formal rules admit of their sharp one-time change (for example, during the periods of revolutions), and informal ones change gradually, over a considerable time. "Formal rules can be changed overnight by political or legal decisions," says D. North, "and informal constraints embodied in customs, traditions, and codes of conduct are much less amenable to human effort" ${ }^{\prime 15}$. We would like to add here that they are imposed by the actors outside the officially authorized channels and often reflect the particular interests of individual groups.

Therefore, institutions contain recognized political norms and values, generally accepted models of political behaviour, forms of organization of political relations, and control over compliance with rules and norms ${ }^{16}$.

${ }^{11}$ Норт Д. Насильство та суспільні порядки. Київ, 2017. С. 300.

12 Норт Д. Насильство та суспільні порядки. Київ, 2017. С. 301.

13 Патнэм Р. Чтобы демократия сработала. Москва, 1996.

14 Фукуяма Ф. Політичний порядок і політичний занепад. Від промислової революції до глобалізації демократії. Київ, 2019. С. 9.

${ }^{15}$ Норт Д. Институты, институциональные изменения и функционирование экономики. Москва, 1997. С. 21.

16 The New Institutionalism: Organizational Factors in Political Life Author(s): James G. March and Johan P. Olsen Source: The American Political Science Review, Vol. 78, No. 3 (Sep., 1984), pp. 734-749. 
Here, an important factor in the functioning of the institutional system and its consequences is the interaction of formal and informal institutions. Informal institutions may supplement the formal ones or substantially alter the consequences of formal rules without violating them. In this case, they increase the efficiency of formal institutions or stabilize their functioning. However, informal institutions can also compete in the political field with formal rules (the constitution, legal codes, regulations, etc.) or replace them completely. The replacement of officially established formal institutions with informal rules usually occurs under the conditions of weakness of state institutions, their inability to exercise authority or perform certain functions.

Transitional societies are characterized by a widespread influence or dominance of informal institutions, which adversely affects democratic transit: constitutional mechanisms are destroyed, citizens are deprived of sovereignty, and authorities - legitimacy ${ }^{17}$. As a result, there is a deformalization of political rules - the substitution of formal institutions by informal rules. The institutional order is formed in a contradictory and hybrid way - from "borrowed" or universalized for democratic political systems formally declared institutions and their gradual replacement at the level of functionality by informal institutions, rooted in the former political order. Populist ideologies at the present stage, through the use of information manipulation technologies, facilitate citizens' perceptions of deformalized rules, creating a reality where the basis of institutional interactions is the absence of clear "game rules", "game of rules", which allows political actors to question the legitimacy of formal institutions to change them in the interest of the ruling elite.

The development of political institutions designates the models of political behaviour and political participation of citizens. In a stable democratic system, the process of institutionalizing of rules determines the rationalization and massification of conventional political behaviour, the differentiation of politics into an autonomous sphere of society. Within an authoritarian political system, the unconventional political behaviour is formed, and the power itself becomes value-irrational. Weak political participation creates "re-institutionalization" when highly organized institutions and norms "drain" the independent activity of citizens. It should be noted that in non-democratic societies, the level of massive political participation does not correspond to its institutionalization and is often simulative.

17 The Oxford Handbook of Political Institutions / Ed. by R. A. W. Rhodes, S. A. Burder, B. A. Rockman.Oxford, 2006. 
Thus, the processes of institutionalization and formalization of new conventional rules, the correlation and interaction of formal and informal institutions at the level of political practice are an indicator of democratization and consolidation of democracy, or vice versa, of the reverse processes of democratic "rollback". The functionality and effectiveness of formal democratic institutions, their rooting in political practices are conditioned by the elites and society's perceptions of them, their willingness to use them, even in spite of their narrow corporate interests, which are mediated not only by rational motives and actors' activities, but by socio-cultural (structural, in terms of transitology) factors political culture and values, self-awareness of society, formed or unformed national identity.

\section{Socio-cultural aspects of democratic transformations}

Transit societies are characterized not only by the crises of division, political participation, legitimacy, integration, but also by the identity crises, or, as S. Rokkan points out, "crises of common understanding of identity" Often, they act as a precondition for a systemic crisis in the initial process of transformation of the political regime, as they destabilize and disintegrate society, while delegitimizing the institutions and values of the political system. The development and consolidation of democracy require the mass support and foundation in the form of political orientations and values, which presupposes the formation and acceptance of a democratic political culture, norms and a renewed value system by the society. We insist that the criterion for the consolidated democracy is not only normative but also the value-based consensus: the transformation period is characterized by institutional changes and introduction of democratic institutions, as well as profound changes in the forms and content of social life, political culture, human values, other socio-cultural factors (traditions, myths, narratives, symbols, etc.). The importance of social traditions, historical experience of interaction and cooperation can be traced here. The value system sets the model and boundaries of the institutional system transformation and that is why it determines the modernization potential of the society, the success or defeat of democracy. Therefore, the effectiveness of the transformation process also depends on the nature and intensity of changes in the value system of the society which is able to act both as a catalyst, accelerating political processes, and a barrier that significantly slows them down. Neglecting the democratic foundations of the value system not only leads to

18 Роккан С. Методы и модели в сравнительном исследовании формирования наций. Политическая наука. 2006. С. 123. 
institutional distortions (dominance of informal institutions, deformation of rules), but also generally imparts the dys-functionality of the transformation outcome. Although political strategies, alliances and actions of individual political actors are at the forefront of the successful democratic transit, the solidarity, trust, presence and activity of networks and civil society associations help to strengthen democratic institutions. Thus, the development of the political system in transit societies is driven by their ability to combine institutional and socio-cultural aspects of their functioning.

The importance of cultural and value-based factors of democratization and consolidation of democracy is conditioned, first of all, by the dependence of the institutional system establishment on the trajectory of the previous development with its cultural context ${ }^{19}$, since the political culture, ideological beliefs, traditions, mental structures are rather stable elements of a political system and change slower than institutions and norms. The discursive refusal of prior and rather established frames of values and ideology that remain at the level of the subconscious does not prevent from their influence on the choice and behaviour of political elites and citizens. Hence, the transition period is marked by the amorphism and hybridism (up to ambivalence) of socio-cultural characteristics, attitude to the past and ideas about the future, the acceptance of new and old myths, characters, heroes. Proneness to conflict, intolerance, search for and transience of political orientations, which are usually subject to manipulation by political elites fighting for power, predominate in transitional societies. The authoritarian inheritance in culture and values can only be overcome by the effective institutional change that provides citizens with democratic values and behaviour norms. But if the elite do not demonstrate such will, then the previous cultural and value norms become a significant obstacle to democracy. It can be argued that cultural norms, traditions and values are informal institutions that usually cannot be quickly and completely formalized but only partially incorporated into formal norms. Accordingly, their deconstruction, comprehension in the new social context is a significant factor in institutional transformation.

Secondly, it is the socio-cultural norms that determine the perception of formal institutions and the possibility of their realization, or their deformation in a situation of incoherence with cultural orientations. In this sense, P. Ricœur considers institutions to be the reflection of the state of will and feelings of a particular human community ${ }^{20}$, and C. Castoriadis - to be

\footnotetext{
${ }^{19}$ Норт Д. Насильство та суспільні порядки. Київ, 2017. 352 с.

${ }^{20}$ Рікер П. Історія та істина. Київ., 2001. С. 302.
} 
a socially sanctioned system in which the functional (legal, symbolic) and imaginary (myth, history) elements are combined ${ }^{21}$. Both the functional and imaginary components of an institution are rooted in collective representations, that is, collective identity. The imaginary component of an institution has a decisive influence on its effectiveness and, accordingly, the legitimation of an institution (support or non-support) by citizens and is the source of its further modifications. Similarly, W. Scott distinguishes three elements (or pillars) of institutional structures - cultural and cognitive, normative, and regulatory. The regulatory pillar represents the system of rules; the normative - norms, values, roles and social relations; the cultural and cognitive - common sense structures ${ }^{22}$. They represent three interrelated, but differentiated, spheres of political legitimacy: legally sanctioned, value-based and morally conditioned, and culturally entrenched. The latter sphere is the deepest basis for the legitimization of institutions and socio-political order through the spread of ideologies, beliefs, archetypes. Certain areas of legitimization may also conflict due to the incoherence of formal regulatory rules and norms, and their cultural and value-based dependence, which is characteristic of transitional regimes. Consequently, the legitimization of institutions also involves knowledge (or its production) about institutions and formation of values. The knowledge about institutions involves the division of roles, the representation of right and wrong actions within certain institutional boundaries ${ }^{23}$. This gives grounds for considering institutions as "cognitive schemes" rooted in the minds of subjects and which are perceived as something "obvious, "self-evident", and the institutionalization of social and political order as a "cognitive process" 24 through which subjects perceive and interpret socio-political reality at the rational and emotional levels. The "cognitive schemas", by way of which individuals and groups perceive the world and interact with one another, are in their turn objectified social and political practices.

Therefore, any institutional order, effective functioning of institutions and norms imply the production of common senses, discourses, and behaviour patterns - the necessary cognitive and symbolic means of legitimizing it, through which it is collectively conceived ("imagined") in the world picture common to most entities and citizens of the world.

21 Касториадис К. Воображаемое установление общества. Москва, 2003. C. 149 .

${ }^{22}$ Scott W.R. Institutions and Organizations: Ideas and Interests, 2013. P. 57-70.

23 Бергер П. Социальное конструирование реальности. Трактат по социологии знания. Москва, 1995. С. 151-153.

${ }^{24}$ Di Maggio P. Introduction. Ch.,1991. P. 15. 
At the same time, institutions, their embeddedness in cultural norms, historical memory, identity structures, political and social practices are an important instrument for constructing a political community and a state in transit societies. Indeed, any social and national community "needs at least some common regulatory institutions that express common political feelings and goals" and form "a sense of legal equality among members of that community" 25 .

At the present stage, the strengthening of informative, communicative, symbolic and psycho-emotional factors of the political process, the hybridity of political and commonplace practices actualize the cultural dimension of democratic transits. To a certain extent, insufficient attention to the cultural factors of democratization has led to the crisis of the transitological paradigm with its linearity and stadiality of development (liberalization democratization - consolidation of the new regime), and the determination of transformation results by the activity and choice of strategies by entities (i.e. political elites). Explaining the causes of crisis, T. Karl noted that the transitological paradigm was unable to integrate the diversity of the everincreasing number of determinants and variables of socio-political transformations into a "hierarchy of explanation" $"$. Among them the sociocultural determinants of transit, in particular, the formation of a new collective identity, are of great importance. After all, by abandoning authoritarian strategies and values, the society experiences a crisis of political identity. If it is applied to the processes of differentiation or even disintegration of the society and domination of local identities, and complex processes of state formation, then the problem of formation of national identity becomes as necessary prerequisite for successful democratic transformations as institutional and economic reforms. In this context, it should be underlined that, as Th. Carothers concluded, in countries "whose population is divided by ethnic, religious, tribal or clan characteristics, democratization is more difficult than in homogeneous societies" 27 . The experience of transit in the post-Soviet countries partly confirmed these trends, leading to scientific discussions about the need to rethink the methodological foundations of the classical transitological paradigm.

Therefore, the necessary factors and conditions for democratization are the correlation with democratic principles of cultural patterns, symbols,

${ }^{25}$ Сміт Е. Д. Національна ідентичність. Київ, 1994. 224 с.

${ }^{26}$ Karl T. L. From Democracy to Democratization and Back: Before Transitions from Authoritarian. St., 2005.

${ }^{27}$ Карозерс Т. Ошибка теории «поэтапной демократизации». Москва, 2007. C. 98 . 
historical narratives, discourse that will form the basis for the national identity and national unity. Supporters of the structural approach in classical transitology, in particular D. Rustow, argued that national unity must precede all other stages of the democratization process, be recognized at an unconscious level, be accepted as something natural ${ }^{28}$. However, if the problem of national unity and identity is not resolved, then, according to A. Melville, "it can become, and most often becomes, an obstacle and a brake on the way to democratic change, 29 .

The latter thesis is an illustration of peculiarities and difficulties of postcommunist transitions in the post-Soviet space. They demonstrated that the incompleteness of the processes of political nation formation, state formation and strengthening significantly influenced the course and result of sociopolitical transformations. C. Offe affirms that transformation in postcommunist societies reflects the threefold transition algorithm: to democracy, to the market, and (re)construction of the nation-state. However, all the three processes must occur simultaneously ${ }^{30}$. Canadian researcher T. Kuzio supplemented this model and substantiated the necessity for Ukraine and other post-Soviet states to realize quadri-transit, within which the four main tasks need to be solved: democratization, marketization, statebuilding, formation of civil nation ${ }^{31}$. Thus, A. Smith's conclusion is convincing: "From a political point of view, national identity serves as a support for the state and its organs", legitimizes the "unified legal rights and obligations introduced by legal institutions that define individual values and character of the nation and reflect ancient customs and rites of the people"32.

The research has lead us to conclude that the basis of socio-political transformations and the effectiveness of the institutional system is a common identity that integrates and represents the cultural features of the society, which transforms it (identity) into a significant element of the political reality. According to A. Wendt, a norm is accepted legitimate when its

28 Растоу Д.А. Переходы к демократии: попытка динамической модели. Москва, 1996. С. 7.

${ }^{29}$ Мельвиль А.Ю. Демократические транзиты, транзитологические теории и посткоммунистическая Россия. Москва, 2000. С. 342.

30 Оффе К. Дилемма одновременности: демократизация и рыночная экономика в Восточной Европе. Повороть истории. Постсоииалистические трансформации глазами немецких исследователей: Т. 2: Постсоциалистические трансформации в сравнительной перспективе. Москва, Берлин, 2003. С. 6-22.

${ }^{31}$ Kuzio T. Transition in Post-Communist States: Triple or Quadruple? Politics., 2001. Р. 174.

${ }^{32}$ Сміт Е.Д. Національна ідентичність. Киев, 1994. С. 25. 
requirements are fully recognized by the corresponding identities ${ }^{33}$, it serves as a common source of norms and institutions, the basis of the interests of policy makers. This means that the legality of the norms and their compliance with the actors' behaviour depend directly on their identity. If the behaviour pattern is forbidden by the norm, it becomes incompatible with identity, which is a prerequisite for mutual transformations.

Transit societies are usually societies with a vacuum of identity, which negatively affects the processes of community's self-awareness and state formation. A weak state in a transit situation can be "privatized" by the elites and be used for extracting rents at the expense of the society. D. North called such societies limited access orders that are aimed at distributing sources of rents for the elite ${ }^{34}$. Elite groups, competing with each other, are constantly trying to change the rules in their favour, are not interested in sustainable institutions and achieving a consensus of value, and, therefore, in establishing the rule of law, which is the main characteristic of open access orders and strong societies. Fragmented elites are also not interested in the national unity, common values, formation of common meanings and discourses, since the manipulation of cultural factors that have an emotional component is the basis of their technologies of reaching power.

In general, in transitional societies, the changing, fragmented and unstable identity of the society and individual is superimposed on the absence of a formed image of a new society, of new meanings, of a new identification model that would be in line with the new (though often only declared) institutions. Therefore, the process of consolidation of the new regime is linked to the construction of a new model of identification that would ensure the integration of the society and become a significant resource, a social asset of the democratic change.

\section{CONCLUSIONS}

The development of post-communist societies is determined by the institutions, ensuring the regularity and predictability of the political behaviour of the actors; the choice of alternatives to political projects, which, however, are determined by the socio-cultural characteristics of the society, technological development, which significantly expands the list of factors that determine the course of transit and its results. Hence, the object of analysis of post-communist transitions is not only the formally institutional aspects of the political process, but the real long-term and situational factors

33 Wendt A. Social Theory of International Politics. Cambridge, 1999. Р. 272-273.

\footnotetext{
${ }^{34}$ Норт Д. Насильство та суспільні порядки. Київ, 2017. 352 с.
} 
of its construction, among which media, discursive and emotional ones have dominated in recent years. This fact accentuates the importance of the anthropological dimension of transients. After all, "institutions are created by humans; being members of the society, they have the capacity to develop and change them"35.

The mediatization and discursivization of democratic transformations in the 21 st century, which allow the use of democratic institutions by populist political forces and oligarchic groups seeking to obtain rent at the expense of the society, necessitate the clarification and rethinking of some provisions and principles of the transitological paradigm. It can be claimed that the systemic transformations of the democratic transition, which occur at the time of the destruction or decline of previous political and economic institutions, are a challenge to the society and its elites. Searching for answers to this challenge determines the diversity of ways and patterns of the transition and their results.

Post-communist transformations also gave empirical grounds to focus attention in the studies of democratic transits on the importance of the state, its power, the duration of its institutions and the compatibility of the political actors' behaviour and the logic of functioning with the development of the state. The formation of nation-states and national identity in Southern and Central-Eastern Europe at the beginning of democratic transits, to a certain extent, determined their success in these regions. The absence of the state in post-Soviet transits, which began after the destruction of the USSR, the need to synchronize democratic transits and processes of state formation are some of the important reasons of their contradiction, re-authorization of a number of the post-Soviet states, incompleteness. F. Fukuyama emphasized that Ukraine faced the same problems in the transit process, and the presence of the state capable of enforcing the laws within the current rules is one of the most important challenges of modern Ukrainian politics ${ }^{36}$. It should be added that throughout the period of state formation and democratization, the Ukrainian society experiences a loss of respect and support of political and state institutions, strengthening of the emphasis on the political participation and self-expression of political actors. That is why, for the post-Soviet states, in our view, the urgent need for social development was and still remains the creation of a common (ideally national) identity at the macro level, through which they represent themselves and are perceived in the globalized world.

\footnotetext{
${ }^{35}$ Норт Д. Институты, институциональные изменения и функционирование экономики. Москва, 1997. С. 20.

${ }^{36}$ Фукуяма Ф. Політичний порядок і політичний занепад. Від промислової революції до глобалізації демократії. Київ, 2019. С. 10.
} 
It is based on common values, cultural norms, value of citizenship, deconstruction of the historical past and understanding of the future. The common Ukrainian identity must answer the questions "who we are or who I am", "who is my Other: is he "other-friend" or "other-foe",37. Despite the six-year aggression of the Russian Federation and hostilities in the Donbas, neither the political elite nor the society has come up with clear answers to these questions and corresponding meanings and narratives.

Thus, building a common Ukrainian identity is a prerequisite for strengthening the state and consolidating the democracy. The common identity integrates, "stitches up" fragmented society and elite, intra-social regional identities. Both the internal and external dimensions of postcommunist states' identity construction are linked to the axiological aspect, that is, the value self-awareness of the community, the formation and institutionalization of the value system shared by the majority. It is one of the main markers of the definition of Friends, Others, and Foes.

Among the negative for the consolidation of the society, the democratic regime, and the formation (construction) of the identity of the Ukrainian community at the macro level are the following factors: 1) weakness of the Ukrainian state, dependence on the external centres of influence of its elite; since the collective identity is connected with "the activity of the state, which in real politics embodies one or another of its interpretations, combines one or another of its understandings in practice" ${ }^{38} ; 2$ ) fragmentation of the political elite, their orientation in the real activity to the use of power and public resources in order to obtain their own, usually short-term benefits, inability to go beyond the group-limited, corporate interests, to offer the society a strategy for development in modern conditions; 3) powerful external informational influence, especially on the part of the Russian Federation throughout the whole period of independence, accompanied by aggressive imposition of ideologemes of the "Russian world", "Slavic brotherhood", as well as the denial of national identity of the Ukrainian people, their language and culture; 4) lack of the formed common value system that would synthesize regional cultures; 5) insufficient development of civil society, its institutionalization, which significantly impedes the formation of civil identity as a common matrix for the development and structuring of other levels. However, the two Maidans, the volunteer movement to assist the army testify to the powerful potential for self-

37 Підлісний Ю. Штрихи до проблеми ідентичності: роздуми в контексті українських евроінтеграційних прагнень Львів, 2012. С. 104.

38 Федотова В. Г. Глобальный капитализм: три великие трансформации. Москва, 2008. С. 408. 
organization of the Ukrainian civil society and its democratic consolidation. The consolidation of democracy (or even another regime) is impossible without the consolidation of society. The problems of identity, the emergence of new value and symbolic systems acceptable to the majority, in the context of socio-political transformations, radical socio-cultural changes and crises, become the priority, determining the course of institutional reforms, their effectiveness and outcome - democratic changes in the distribution of power, in the principles of communication of the authorities and society, and ultimately, the consolidation of a democratic society, or, conversely, authoritarian consolidation.

It should be emphasized that Ukraine, having inherited authoritarian values and paternalistic models of political behaviour from the previous Soviet system, found itself in a difficult situation of establishing democracy, because, as F. Fukuyama rightly points out, the states that had left the Soviet Union remained the ability to subdue the citizens, but could not provide the full range of services such as health care, sound financial management or social security at the level expected from the state by modern societies ${ }^{39}$. These needs determine, from election to election, the discursive tone of election campaigns of the political forces, which actively fight for the power and resources in Ukraine, while offsetting the cultural and value-integrative aspects of transformation processes. Similar to F. Fukuyama, we draw attention to the high civic potential of democratization of the Ukrainian society, the successful completion of which is important not only for Ukraine but for the whole world, regional international relations.

\section{SUMMARY}

Institutional and socio-cultural dimensions of political transformations in post-communist societies are analysed. Their content examines the processes of institutionalization and formalization of the new conventional rules (institutions) of the political elites' struggle for power, the formation of democratic values and behaviours. It is specified that the processes of mediatization, discursivization of political processes, destructive manipulative technologies, and the spread of populist ideologies contribute to the de-legitimization and de-formalization of democratic institutions and create grounds for strengthening the authoritarian tendencies in modern transit societies. It is emphasized that the results of socio-political transformations can be either the consolidation of the democratic regime or the formation and consolidation of a new model of the authoritarian regime.

39 Фукуяма Ф. Політичний порядок і політичний занепад. Від промислової революції до глобалізації демократії. Київ, 2019. С. 10. 
It is found out that the effectiveness of the transformation process is largely determined by the socio-cultural characteristics of the society, the intensity of changes in the value-based and symbolic systems of the society. Another important factor in the success of the transformation process is the formation of the nation-state and common identity at the macro-level of the society. The peculiarities and difficulties of the democratic transformations in Ukraine, their cyclical nature and incomplete state are outlined. The interdependence of the processes of consolidation of the new regime and the formation of the nation-state identity in Ukraine is substantiated.

\section{REFERENCES}

1. Банс В. Элементы неопределенности в переходный период. Москва : Полис. 1993. № 1. С. 44-51.

2. Бергер П. Социальное конструирование реальности. Трактат по социологии знания / П. Бергер, Т. Лукман. Москва : «Медиум», 1995. C. $151-153$.

3. Водак Рут. Политика страха. Что значит дискурс правых популистов?; пер. с англ. Харьков : изд-во «Гуманитарный Центр», 2018. $404 \mathrm{c}$.

4. Карл Т.Л. Демократизация: концепты, постулаты, гипотезы. Размышления по поводу применимости транзитологической парадигмы при изучении посткоммунистических трансформаций / Т.Л. Карл, Ф. Шмиттер. Москва, Полис. 2004. № 4. С. 10-11.

5. Карозерс Т. Ошибка теории «поэтапной демократизации». Pro et Contra. 2007. № 1. C. 85-102.

6. Касториадис К. Воображаемое установление общества. Корнелиус Касториадис; пер. с франц. Г. Волковой, С. Офертаса. Москва : Гнозис; Логос, 2003. С. 149. (Cornelius Castoriadis. L'institution imaginaire de la societe)

7. Мельвиль А.Ю. Демократические транзиты, транзитологические теории и посткоммунистическая Россия. Политическая наука в России: интеллектуальный поиск и реальность: Хрестоматия / отв. ред., сост. А.Д. Воскресенский. Москва : МОНФ ; ООО «Изд. центр научных и учебных программ», 2000. С. 337-368.

8. Норт Д. Институты, институциональные изменения и функционирование экономики. Москва : Фонд экономической книги «Начала». 1997. $180 \mathrm{c.}$

9. Норт Д. Насильство та суспільні порядки. Київ : Наш формат. 2017. $352 \mathrm{c}$.

10. Оффе К. Дилемма одновременности: демократизация и рыночная экономика в Восточной Европе. Повороты истории. 
Постсоциалистические

трансформации

глазами

немецких исследователей: в 2 т. Т. 2: Постсоциалистические трансформации в сравнительной перспективе. Санкт-Петербург, Москва, Берлин, 2003. $493 \mathrm{c}$.

11. Патнэм Р. Чтобы демократия сработала. Москва : Ad Marginem. 1996. (107)

12. Підлісний Ю. Штрихи до проблеми ідентичності: роздуми в контексті українських евроінтеграційних прагнень. Наукові записки УКУ. 2012. Ч. 3 : Філософія, вип. 1. С. 103-110.

13. Пшеворский A. (Adam Przeworski) Демократия и рынок. Политические и экономические реформы в Восточной Европе и Латинской Америке ; пер. с англ. В.А. Бажанов [и др.] ; ред. В.А. Бажанов. Москва : РОССПЭН, 1999. 320 с.

14. Растоу Д.А. Переходы к демократии: попытка динамической модели. Полис. 1996. № 5. С. 5-15.

15. Рікер П. Історія та істина. Київ : Видавничий дім «КМ Академія», 2001. С. 302.

16. Роккан С. Методы и модели в сравнительном исследовании формирования наций. Политическая наука. 2006. №4. С. 102-123.

17. Сміт Е. Д. Національна ідентичність ; пер. $з$ англ. П. Таращука. Київ : Основи, 1994. 224 с.

18. Федотова В.Г. Глобальный капитализм: три великие трансформации / В.Г. Федотова, В.А Колпаков, Н.Н. Федотова. Москва : Культурная революция, 2008. 608 с.

19. Фукуяма Ф. Політичний порядок і політичний занепад. Від прадавніх часів до Французької революції / пер. з англ. Тарас Цимбал і Роман Корнута. Київ : Наш Формат, 2019. 576 с.

20. Фукуяма Ф. Політичний порядок і політичний занепад. Від промислової революції до глобалізації демократії / пер. з англ. Тарас Цимбал і Роман Корнута. Київ : Наш Формат, 2019. 608 с.

21. . P. Di Maggio, W. Powell. Introduction. The New Institutionalism in Organizational Analysis. Chicago : University of Chicago Press, 1991. P. 15.

22. Karl T.L. From Democracy to Democratization and Back: Before Transitions from Authoritarian Rule. Center on Democracy, Development, and The Rule of Law (CDDRL), Stanford Institute on International Studies Working Papers, 2005. № 45. Access of mode: http://iisdb.stanford.edu/pubs/20960/Karlsep05.pdf.

23. Kuzio T. Transition in Post-Communist States: Triple or Quadruple? Politics. 2001. Vol. 21. № 3. P. 168-177. 
24. Scott W.R. Institutions and Organizations: Ideas and Interests ; 4th ed. Thousand Oaks : Sage Publications 2013. P. 57-70.

25. The New Institutionalism: Organizational Factors in Political Life Author(s): James G. March and Johan P. Olsen Source: The American Political Science Review, Vol. 78, No. 3 (Sep., 1984), pp. 734-749.

26. The Oxford Handbook of Political Institutions / Ed. by R. A. W. Rhodes, S. A. Burder, B.A. Rockman.Oxford, 2006.(260).

27. Wendt A. Social Theory of International Politics. Cambridge : Cambridge University Press, 1999. P. 272-273.

\section{Information about authors: Sviderska O. I.,}

Candidate of Political Science, Assistant Professor of the Department of Theoretical and Practical Psychology Lviv Polytechnic National University 12, Stepan Bandera Str, Lviv, Ukraine

Uhryn L. Ya., Candidate of Political Science, Associate Professor of the Department of Theory and History of Political Science Ivan Franko National University of Lviv 1, Universitetskaya Str., Lviv, Ukraine 